\title{
Antifungal activity of linalool in cases of Candida spp. isolated from individuals with oral candidiasis
}

\author{
I. J. Dias ${ }^{a}$, E. R. I. S. Trajano ${ }^{a}$, R. D. Castro ${ }^{b}$, G. L. S. Ferreira ${ }^{b}$, H. C. M. Medeiros ${ }^{c}$ and \\ D. Q. C. Gomes ${ }^{a *}$ \\ a'Departamento de Odontologia, Universidade Estadual da Paraíba - UEPB, Rua Juvêncio Arruda, s/n, Campus \\ Universitário Bodocongó, CEP 58109-790, Campina Grande, PB, Brazil \\ ${ }^{\text {b}}$ Departamento de Odontologia, Universidade Federal da Paraíba - UFPB, Cidade Universitária, s/n, Castelo Branco, \\ CEP 58051-900, João Pessoa, PB, Brazil \\ 'Departamento de Odontologia, Universidade Federal do Rio Grande do Norte - UFRN, Avenida Senador Salgado Filho, \\ 1787, CEP 59056-000, Natal, RN, Brazil \\ *e-mail: dqcgomes@hotmail.com
}

Received: October 25, 2016 - Accepted: December 21, 2016 - Distributed: May 31, 2018

(With 1 figure)

\begin{abstract}
This study analyzed the antifungal activity of phytoconstituents from linalool on Candida spp. strains, in vitro, isolated from patients with clinical diagnoses of oral candidiasis associated with the use of a dental prosthesis. Biological samples were collected from 12 patients using complete dentures or removable partial dentures and who presented mucous with diffuse erythematous or stippled features, indicating a clinical diagnosis of candidiasis. To identify fungal colonies of the genus Candida, samples were plated onto CHROMagar Candid ${ }^{\circledR}$. The antifungal activity of linalool, a monoterpene unsaturated constituent of basil oil, was performed using the broth microdilution technique. Then, the minimum inhibitory concentration (MIC), the two subsequent stronger concentrations and the positive controls were subcultured on Sabouraud Dextrose Agar plates to determine the minimum fungicidal concentration (MFC). The experiments were performed in triplicate and nystatin was used as a positive control in all tests. Diagnoses of oral candidiasis were verified in eight patients (66.6\%) and the most prevalent fungal species was Candida albicans (37.5\%), followed by Candida krusei (25.0\%); and Candida tropicalis (4.2\%). The best antifungal activity of linalool was observed on Candida tropicalis $(\mathrm{MIC}=500 \mathrm{mg} / \mathrm{mL}$ ), followed by Candida albicans $(\mathrm{MIC}=1.000 \mathrm{mg} / \mathrm{mL}$ ), and Candida krusei $(\mathrm{MIC}=2.000 \mathrm{mg} / \mathrm{mL})$.Under the study conditions and based on the results obtained, it can be concluded that the Candida strains tested were susceptible to linalool.
\end{abstract}

Keywords: candidiasis, linalool, phytotherapy.

\section{Atividade antifúngica do linalol em casos de Candida spp. isolados de indivíduos com candidíase oral}

\section{Resumo}

Este estudo analisou a atividade antifúngica do fitoconstituinte linalol em cepas de Candida ssp, in vitro, isolados de pacientes com o diagnóstico clínico de candidíase oral associado ao uso de prótese dentária. As amostras biológicas foram coletadas de 12 pacientes portadores de próteses totais ou próteses parciais removíveis e que apresentavam características de mucosa eritematosa difusa ou pontilhadas, indicando um diagnóstico clínico de candidíase. Para identificar colônias de fungos do gênero Candida, as amostras foram semeadas em CHROMagar Candida ${ }^{\circledR}$. A atividade antifúngica do linalol, um componente insaturado monoterpene de óleo de manjericão, foi realizada através da técnica de microdiluição em caldo. Em seguida, a concentração inibitória mínima (MIC), as duas concentrações consecutivas mais fortes e os controles positivos foram subcultivados em placas de Agar Sabouraud Dextrose para determinar a concentração fungicida mínima (MFC). Os experimentos foram realizados em triplicata e a nistatina foi usada como controle positivo em todos os testes. O diagnóstico de candidíase oral foi comprovado em oito pacientes $(66,6 \%)$ e as espécies de fungos mais prevalentes foram Candida albicans (37,5\%), seguido por Candida krusei (25,0\%); e Candida tropicalis (4,2\%). A melhor atividade antifúngica do linalol foi observada em Candida tropicalis $(\mathrm{MIC}=500 \mathrm{mg} / \mathrm{ml})$, seguido por Candida albicans $(\mathrm{CIM}=1,000 \mathrm{mg} / \mathrm{mL})$, e Candida $\mathrm{krusei}(\mathrm{CIM}=2,000 \mathrm{mg} / \mathrm{mL})$. Sob as condições do estudo e com base nos resultados obtidos, pode-se concluir que as estirpes de Candida testadas foram susceptíveis a linalol.

Palavras-chave: candidíase, linalool, fitoterapia. 


\section{Introduction}

Yeasts of the genus Candida are symbiotic microorganisms that remain in equilibrium with the human body. However, in certain individuals and in specific situations, they can develop the parasitic form, producing diseases known as oral candidiasis. This is considered the most common opportunistic fungal infection in this host (Budtz-Jorgensen, 2000).

Oral candidiasis is also known as denture stomatitis or erythematous candidiasis, when it occurs in cases related to complete dentures or removable partial dentures. Denture stomatitis is the most common infectious disease that affects the mucosa of the palate and the alveolar ridge that is in direct contact with the denture base (Muneer et al., 2011). The rate of development ranges between $25-67 \%$, is more prevalent in women, and the prevalence is proportional to increasing age. Other factors significantly favoring the cause of denture stomatitis include traumatic occlusion, poor oral and prosthesis hygiene, the period of prosthesis usage, allergy to the prosthesis material and the residual monomer, smoking, dry mouth, systemic conditions, diabetes and low host immunity (Naik and Pai, 2011).

Candida albicans is the most prevalent and pathogenic species among those involved in the development of denture stomatitis. Candida tropicalis, Candida krusei, Candida parapsilosise and Candida guilliermondii can also form part of the course of the disease, however, C. albicans represents more than $80 \%$ of clinical isolates (Salerno et al., 2011).

The treatment of candidiasis consists of the combination of a topical or systemic antifungal agent, patient guidance on prosthesis hygiene and examination to determine whether the prosthesis should be replaced. Nystatin and miconazole are the initial drugs of choice. In cases where the topical treatment does not show results, systemic treatment is initiated and fluconazole is the most prescribed drug. However, the use of conventional antifungal agents can trigger the occurrence of certain undesirable factors, such as the appearance of adverse reactions and an increase in fungal resistance (Zore et al., 2011).

The resistance of Candida spp. to antifungal drugs is related to their prolonged use. Among the mechanisms that contribute to this phenomenon are the overexpression or mutation of genes, such as ERG11, CDR1, CDR2 and MDR1 that encode efflux pumps (Sanglard et al., 2003; Basso Junior et al., 2010; Manoharlal et al., 2010), as well as the ERG-3 gene encoding the enzyme $\Delta^{5.6}$ sterol dessaturase, important in the synthesis of ergosterol (Sanglard et al., 2003) and alterations in the lipid composition of the fungal plasma membrane, which hinders the influx of the drug into the cell (Loffler et al., 2000). It should be pointed out that these mechanisms can occur simultaneously, contributing to increase the phenomenon of resistance.

The emergence of these mechanisms of resistance, coupled with the reduced number of antifungal agents currently available, drive the search for new potential substances for use in the treatment of fungal infections.
In this context, products of natural origin (Newman and Cragg, 2012; Camargo et al., 2016). Among the classes of compounds isolated from plants with antibacterial and antifungal properties, essential oils present the highest amount of phytochemicals with active biological properties, showing outstanding diversity in their chemical composition, and being active against a variety of microorganisms (Sartoratto et al., 2004).

Linalool is a phytochemical that is a known component of essential oils of several kinds of herbs, such as perilla (Perilla frutescens), rosemary (Rosmarinus officinalis L.), and mastic (Pistacia lentiscus), being the major constituent of basil oil (Ocimum Basilicum L.). It is a monoterpene unsaturated alcohol that is widely used in the perfume, cosmetics and food industries, and has also been tested as bactericide and fungicide (Bezerra et al., 2013; Blank et al., 2007; Luz et al., 2009).

The search for new chemical agents capable of inhibiting the growth of microorganisms involved in oral candidiasis has been heightened because of the limited number of antifungal agents available for treatment. Therefore, the purpose of this study was to evaluate the antifungal potential of linalool on clinical strains of C. albicans, C. tropicalis and $C$. krusei, isolated from the oral cavity of individuals diagnosed with oral candidiasis associated with the use of a dental prosthesis.

\section{Material and Methods}

This research is an in vitro experimental study using 12 samples from individuals of both sexes, who presented a clinical diagnosis of oral candidiasis associated with prosthesis use. Following the approval by the Human Research Ethics Committee of the State University of Paraíba (UEPB), under protocol no. 731152 and CAAE 32255214.6.0000.5187, the individuals were chosen by convenience from among those attended at the Dental School outpatient clinic by health professionals.

After filling out a questionnaire, biological samples were collected from the affected mucosal area of the participants using a sterile swab and then seeded in CHROMagar Candida ${ }^{\circledR}$ to identify specific species in the fungal colonies. The inclusion criterion was the use of dentures, and the exclusion criterion was the use of antibiotics in the three months prior to the examination.

The test for determining the antifungal activity of the phytochemical substance was performed in the Oral Microbiology Laboratory, located in the Tropical Medicine Center, which forms part of the Health Sciences Center of the Federal University of Paraíba, Brazil. Five different strains of clinical isolates were used in the tests, which were identified by codes and selected according to origin or isolation location: C. albicans CA 032 (denture base), CA 051 (mucosa); C. tropicalis CT 011 (mucosa); and C. krusei CK 032 (denture base), CK 031 (mucosa), collected from patients treated at the Dental School outpatient clinic of the UEPB. The strains were maintained on Sabouraud dextrose agar (SDA), and refrigerated. 
Linalool was obtained from Quinari ${ }^{\circledR}$ (Ponta Grossa, Paraná, Brazil), a company that produces and sells essential oils and their derivatives on an industrial scale. Technical product information provided by the manufacturer states that the oil with has a density of $0.85 \mathrm{~g} / \mathrm{ml}$ and its lot number was 02235 .

Determining the minimum inhibitory concentration (MIC) of linalool was performed using the microdilution technique. Initially, $100 \mu \mathrm{L}$ of Sabouraud dextrose broth (SDB) (HIMEDIA ${ }^{\circledR}$, Mumbai, Maharashtra, India) were distributed in 96-well plates. Then $100 \mu \mathrm{L}$ of linalool were transferred to the first well at an initial concentration of $2000 \mu \mathrm{g} / \mathrm{mL}$, which was serially diluted by the removal of an aliquot of $100 \mu \mathrm{L}$ of the most concentrated well to the next well. Aliquots of $100 \mu \mathrm{L}$ of the appropriate inoculum for each strain tested were dispensed in the wells of each column on the plate, which was prepared according to CLSI standards, using SDB at a final concentration of $2.5 \times 10^{3} \mathrm{UFC} / \mathrm{mL}$ (CLSI, 2002).

After determining the MIC, the inhibitory concentration, the two subsequent stronger concentrations, and the positive controls were subcultured onto dishes containing SDA. After $24 \mathrm{~h}$ of incubation at $37^{\circ} \mathrm{C}$, the minimum fungicidal concentration, defined as the lowest product concentration that prevented visible growth in the subcultures, was determined by examining the Petri dishes, that is, the lowest concentration that effectively eliminated the fungus (Deswall and Chand, 1997).

After the incubation period, to confirm the presence of viable microorganisms, $50 \mu \mathrm{L}$ of TCT (2,3,5-triphenyl tetrazolium chloride; Sigma-Aldrich ${ }^{\circledR}$, Saint Louis, Missouri, USA) stain was placed in each well (see Figure 1). This stain reveals the activity of dehydrogenase enzymes involved in the process of cellular respiration. Thus, this method distinguishes live samples, stained in red, from non-viable samples, which maintain their color (Deswall and Chand, 1997). Therefore, the MIC was considered to be the lowest concentration of the test product capable of producing visible inhibition in the growth of the yeast strains used in the microbiological assays.

\section{Results}

During this study, 12 individuals presented mucosal lesions associated with the use of dentures. Among these, eight $(66.7 \%)$ had a positive mycological diagnosis for oral candidiasis and four (33.3\%) were negative. Of the eight individuals, seven were women $(87.5 \%)$ with an average age of 61 years old. Six (75.0\%) of the prostheses used by the individuals assessed lacked adequate stability and retention. Continuous use of a dental prosthesis, even during sleep, was reported by six individuals $(75.0 \%)$, a fact that contributes to colonization of the oral cavity by yeasts. In addition, five individuals (62.5\%) reported inadequate hygiene and presented painful symptoms. Half of the individuals $(50.0 \%)$ reported having diabetes (see Table 1).

Table 2 shows the percentage frequency of the main species of fungi identified by mycological laboratory analysis. The fungal species identified were C. albicans (37.5\%), followed by C. krusei (25.0\%) and C. tropicalis (4.2\%).

All of the Candida strains used in this study were sensitive to the phytochemical linalool at the concentrations tested. Table 3 shows the results of tests to determine the

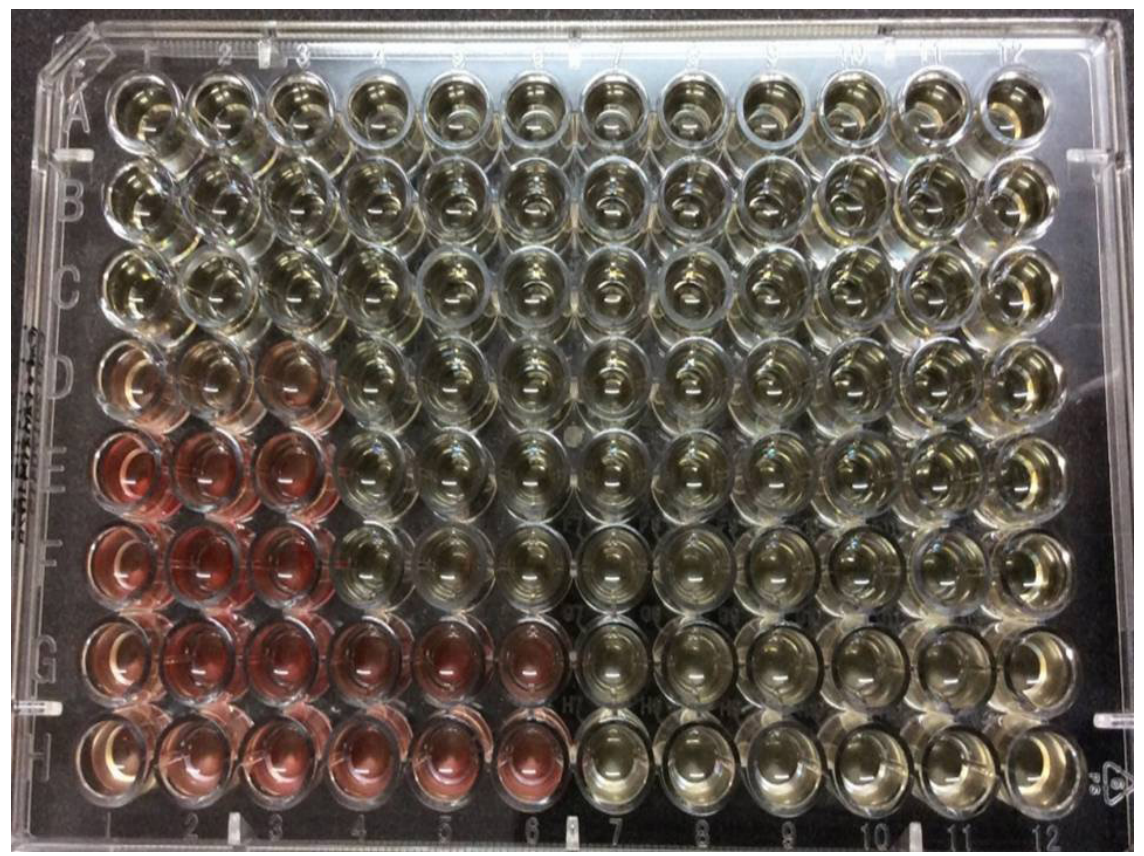

Figure 1. Test for the confirmation of the MIC, using the TCT. 
antifungal activity of linalool. The MIC and MFC values of the phytochemical tested, as well as those of Nystatin, against the clinical strains of $C$. albicans, C. tropicalis and $C$. krusei are also presented.

Table 1. Absolute frequencies and percentages of variables related to the characteristics of individuals with clinical diagnosis of candidiasis associated with the use of a dental prosthesis.

\begin{tabular}{lcc}
\hline \multicolumn{1}{c}{ Variable } & Frequency & Percentage \\
\hline Sex & 7 & \\
Female & 1 & 87.5 \\
Male & 1 & 12.5 \\
Presence of systemic disease & 12.5 \\
Diabetes & 3 & 37.5 \\
Hypertension & 3 & 37.5 \\
Diabetes and & 1 & 12.5 \\
Hypertension & & \\
No & 6 & 75.0 \\
Continuous use of dental prosthesis & 25.0 \\
Yes & 2 & \\
No & 2 & 25.0 \\
Dentures with stability and retention & 75.0 \\
Yes & 2 & \\
No & 6 & 62.5 \\
Inadequate hygiene & & 37.5 \\
Yes & 5 & 62.5 \\
No & 3 & 37.5 \\
Presence of painful symptoms & \\
Yes & 5 & \\
No & 3 & \\
Laboratory diagnosis of candidiasis & \\
Yes & 8 & \\
No & 4 & \\
\hline
\end{tabular}

Table 2. Percentage frequency of the main species of fungi identified by mycological laboratory analysis.

\begin{tabular}{lr}
\multicolumn{1}{c}{ Fungal species } & \% \\
\hline C. albicans & 37.5 \\
C. krusei & 25.0 \\
C. tropicalis & 4.2 \\
Negative & 33.3 \\
Total & $\mathbf{1 0 0 . 0}$ \\
\hline
\end{tabular}

\section{Discussion}

The choice of the methodology for identifying yeast strains in the oral cavity was determined by the type of injury under investigation, because each technique has its own advantages and disadvantages (Ferreira et al., 2012). The oral swab technique was used herein because, in addition to fulfilling the research requirements, it is a technique that is easily accepted by people and is low cost, fast and convenient.

Regarding patient sex, most of the individuals with a positive mycological diagnosis were female $(87.5 \%)$ with an average age of 61 years old. This result is consistent with other studies cited in the scientific literature, in which the prevalence of women with candidiasis was $66.7 \%$, with an average age of 61.3 years old. The association of candidiasis with prosthesis use is more common in women than in men in individuals over 40 years old due to decreased production of hormones, and this may be associated with a greater predisposition for developing lesions in the oral mucosa related to the use of a dental prosthesis (Melo et al., 2013).

This difference can also be justified by the increased demand for health services by women, which favors diagnosis. It also seems reasonable to assume that women use dentures for longer, including nighttime use, for esthetic reasons, which favoring the occurrence of injury and opportunistic infection (Arnaud et al., 2012).

Individuals with diabetes are more likely to develop infections in the oral cavity. Susceptibility to infections like candidiasis is favored by hyperglycemia, decreased salivary flow and changes in saliva composition (Alves et al., 2006; Stramandinoli et al., 2010; Barbosa et al., 2011). The results of this study corroborate this observation, among the eight individuals with a positive diagnosis, four reported having diabetes.

As for the frequency of dental prosthesis use, only two $(25.0 \%)$ of the individuals confirmed that the use theirs only during the day. Most of the respondents reported continuing to use the prosthesis while sleeping, a factor that likely contributed to the onset of the lesion in the individuals. These findings are similar to those observed by Bomfim et al., (2008) who reported that $71.2 \%$ of individuals slept with the prosthesis.

Based on this data, the importance of counseling patients to remove the prosthesis during sleep is confirmed. According to Melo et al., (2013) relaxation of and resting

Table 3. Values for minimum inhibitory concentration (MIC) and minimum fungicidal concentration (MFC) of phytochemical and Nystatin against C. albicans, C. tropicalis and C. krusei in $\mu \mathrm{g} / \mathrm{mL}$.

\begin{tabular}{|c|c|c|c|c|}
\hline \multirow{2}{*}{ Microorganisms } & \multicolumn{2}{|c|}{ Linalool } & \multicolumn{2}{|c|}{ Nystatin } \\
\hline & MIC $(\mu \mathrm{g} / \mathrm{mL})$ & MFC $(\mu \mathrm{g} / \mathrm{mL})$ & MIC $(\mu \mathrm{g} / \mathrm{mL})$ & MFC $(\mu \mathrm{g} / \mathrm{mL})$ \\
\hline Candida albicans 032 & 2000 & 2000 & 0.39 & 0.39 \\
\hline Candida albicans 051 & 1000 & 2000 & 0.39 & 0.78 \\
\hline Candida tropicalis 011 & 500 & 500 & 0.39 & 0.39 \\
\hline Candida krusei 032 & 2000 & 2000 & 0.39 & 0.78 \\
\hline Candida krusei 031 & 2000 & 2000 & 0.39 & 0.78 \\
\hline
\end{tabular}


the tissues, together with the cleaning action exerted by the saliva, tongue and cheeks, are essential to the health of the oral mucosa.

In this study, $75.0 \%$ of the prostheses used by the individuals lacked adequate stability and retention. According to Barbosa et al. (2011) and Melo et al., (2013) the tissues of the mouth undergo changes due to the constant use of a prosthesis, which must be accompanied by a professional. Failure to follow-up patients can result in ill-fitting dentures that cause discomfort, pain and injuries that can favor the emergence of pathological conditions in the oral cavity and exacerbating the pathogenic action of microorganisms.

Of the eight patients with candidiasis, five (62.5\%) presented signs and symptoms, including hemorrhagic petechiae, pain, burning sensation, itching, halitosis and dry mouth. According to Barbosa et al. (2011) candidiasis may be accompanied by pain symptoms, with variable condition of erythema and hemorrhagic petechiae, located in the area of the upper denture edges.

C. albicans is the primary species involved in inflammatory processes associated with the use of a dental prosthesis, with a prevalence of $32.0 \%$ compared with other Candida species (Melo et al., 2013). This finding confirms the results of this work, since it presents a higher prevalence of C. albicans of $37.5 \%$, followed by C. krusei (25.0\%) and C. tropicalis (4.2\%). According to Menezes et al. (2011) the presence of this fungus is not necessarily indicative of disease, since it can be isolated in about $40.0 \%$ of healthy individuals. However, under certain conditions, such as low host immunity, diabetes, use of a prosthesis and lack of oral hygiene, these fungi can behave as opportunistic pathogens and cause infections, such as erythematous candidiasis.

Currently, non-albicans Candida species have shown greater importance in the etiology of fungal infections, particularly regarding the problem of fungal resistance. Concerns with the emergence of strains resistant to conventional antifungal drugs have increased, and conducting resistance surveillance studies of antifungal agents have become more frequent. Species like C. krusei have an intrinsic resistance to fluconazole, whereas other species, such as $C$. glabrata and C. tropicalis, have shown increasing acquired resistance (Abrantes et al., 2013).

Linalool is a chemical constituent of great value in the cosmetics and perfumery market. It has been widely tested as an acaricide, bactericide and fungicide. In medicine, it has been successfully used as a sedative and anticonvulsant (Blank et al., 2007). Analysis of the results of this study indicate the antifungal activity of linalool against $C$. albicans, C. tropicalis and C. krusei in all the experiments performed. The MIC values obtained show different results among the strains tested. Linalool had the lowest inhibitory concentration against $C$. tropicalis strains $(\mathrm{MIC}=500 \mu \mathrm{g} / \mathrm{mL})$, followed by $C$. albicans $(1000 \mu \mathrm{g} / \mathrm{mL})$ and C. krusei $(2000 \mu \mathrm{g} / \mathrm{mL})$. Linalool had a clear inhibitory effect on the growth of $C$. tropicalis.
The biological activity of the product was interpreted using MIC values, according to the criteria adopted by Sartoratto et al. (2004): the biological activity of a product may be interpreted as excellent/good activity if the MIC ranges from 50 to $500 \mu \mathrm{g} / \mathrm{mL}$; if compounds show a variation in the MIC from 600 to $1500 \mu \mathrm{g} / \mathrm{mL}$, they are considered to have moderate activity, and in cases when the MIC is greater than 1500 , it is considered to have weak activity. Thus according to the parameters defined by the author, in this study, linalool presented good antimicrobial activity for strains of $C$. tropicalis, and moderate activity against the species $C$. albicans.

The findings outlined herein are consistent with the results presented by Zore et al. (2011) in which linalool was shown to be effective on all isolates of C. albicans (susceptible and resistant to FLC) and non-albicans Candida, in inhibiting $\leq 0.064 \%(\mathrm{v} / \mathrm{v})$ and showing fungicidal activity. According to the author, linalool MFC indicted a better performance than citral, causing the death of $99 \%$ of the inoculum within 7.5 minutes of exposure, while 120 minutes were required for the same action by the citral.

The genetic variability among different clinical Candida species, as well as the possibility that there are forms of acquired resistance in some species due to the challenges presented by the oral cavity and/or prior contact with antifungals, generate differences in the approach to and discussion of the results, but these should be seen as advances in the literature, since the study of clinically isolated strains better reflects the realities of treatment.

The essential oils and their components, such as linalool, can interfere in the biosynthesis of the cell wall and/or can increase the ionic permeability of the fungal cell membrane (Pierce et al., 2013; Sookto et al., 2013). They may represent an important source of new molecules capable of controlling oral fungal infections.

The choice of clinical samples in the development of the microbiological tests, avoiding the standard practice of using marketed strains, is justified by the need for information for a specific diagnosis of the fungal microbiota present in the patients who participated. Moreover, it is rare for studies to report on the inhibitory effect of phytotherapy linalool on species of the genus Candida, particularly C. tropicalis, which was the species the proved most sensitive to the product under investigation.

\section{Conclusions}

Analysis of the results of this study indicated that the Candida strains obtained were susceptible to linalool, with the exception of $C$. krusei. Linalool represents a strong candidate among commercially available natural products with antifungal activity for treatment of infections by clinical species of the genus Candida. However, further studies are required to more clearly determine its mechanisms of action and toxicity, prior to its use in therapeutic applications. 


\section{Acknowledgements}

We thank CNPq and Oral Microbiology Laboratory (NUMETROP) of the Federal University of Paraíba (UFPB) for support this research.

\section{References}

ABRANTES, M.R., LIMA, E.O., MEDEIROS, M.A.P., MENEZES, C.P., GUERRA, F.Q.S. and MILAN, E.P., 2013 [viewed 25 October 2016]. Antifungal activity of essential oils on non Candida albicans yeasts. Revista Brasileira Farmacologia [online], vol. 3, pp. 227-233. Available from: http://www.rbfarma. org.br/files/rbf-v94n3-05.pdf

ALVES, P.M., LEITE, P.H.A.S., PEREIRA, J.V., PEREIRA, L.F., PEREIRA, M.S.V., HIGINO, J.S. and LIMA, E.O., 2006. Antifungal activity of the extract of Psidium guajava Linn. ("goiabeira") upon leavens of Candida of the oral cavity: an in vitro evaluation. Revista Brasileira Farmacognosia, vol. 16, pp. 192-196. http://dx.doi.org/10.1590/S0102-695X2006000200010.

ARNAUD, R.R., SOARES, M.S.M., SANTOS, M.G.C. and SANTOS, R.C., 2012. Prevalence and Correlation With Age and Gender. Revista Brasileira de Ciências da Saúde, vol. 16, pp. 59-62. http://dx.doi.org/10.4034/RBCS.2012.16.01.09.

BARBOSA, T.P.M., SANTANA, T.S.S., LOPES-JUNIOR, R.M., BATISTA, J.R., SILVEIRA, L.F. and FREITAS, A.P., 2011 [viewed 25 October 2016]. Oral injuries associated with the use of complete enture. Revista Saúde.com [online], vol. 7, pp. 133-142. Available from: http://www.uesb.br/revista/rsc/v7/v7n2a06.pdf

BASSO JUNIOR, L.R., GAST, C.E., MAO, Y. and WONG, B., 2010. Fluconazole transport into Candida albicans secretory vesicles by the membrane proteins Cdr1p, Cdr2p, and Mdr1p. Eukaryotic Cell, vol. 9, no. 6, pp. 960-970. PMid:20348384. http://dx.doi.org/10.1128/EC.00355-09.

BEZERRA, L.M.D., FERREIRA, G.L.S., SILVA, I.C.G. and CASTRO, R.D., 2013. Antibacterial in vitro activity of phytochemicals in dental biofilm microorganisms. Revista Brasileira de Ciências da Saúde, vol. 17, pp. 79-84. http://dx.doi. org/10.4034/RBCS.2013.17.01.10.

BLANK, A.F., SOUZA, E.M., ARRIGONI-BLANK, M.F., PAULA, J.W.A. and ALVES, P.B., 2007. Basil: cultivate basil linalool type. Pesquisa Agropecuária Brasileira, vol. 42, pp. 1811-1813. http:// dx.doi.org/10.1590/S0100-204X2007001200020.

BOMFIM, I.P.R., SOARES, D.G., TAVARES, G.R., SANTOS, R.C., ARAUJO, T.P. and PADILHA, W.W.N., 2008 [viewed 25 October 2016]. Prevalence of oral mucosa lesions. Pesquisa Brasileira em Odontopediatria e Clinica Integrada [online], vol. 8, pp. 117-121. Available from: http://revista.uepb.edu.br/index. php/pboci/article/viewFile/250/181

BUDTZ-JORGENSEN, E., 2000. Ecology of Candida: associated denture stomatitis. Microbial Ecology in Health and Disease, vol. 12 , no. 3, pp. 171-185. http://dx.doi.org/10.1080/089106 000750051846.

CAMARGO, L.E.A., PEDROSO, L.S., VENDRAME, S.C., MAINARDES, R.M. and KHALIL, N.M., 2016. Antioxidant and antifungal activities of Camellia sinensis (L.) Kuntze leaves obtained by different forms of production. Brazilian Journal of Biology $=$ Revista Brasileira de Biologia, vol. 76, no. 2, pp. 428434. PMid:26983085. http://dx.doi.org/10.1590/1519-6984.18814.
CLINICAL LABORATORY STANDARDS - CLSI, 2002. Reference method for broth dilution antifungal susceptibility testing of yeasts. Wayne: CLSI.

DESWALL, D.P. and CHAND, U., 1997 [viewed 25 October 2016]. Standardization of the tetrazolium test for viability estimation in ricebean. Seed Science and Technology [online], vol. 25, pp. 409-417. Available from: http://www.scielo. br/scielo.php?script $=$ sci_nlinks\&ref $=000092 \&$ pid $=$ S01013122201200020002000013\&lng $=\mathrm{pt}$

FERREIRA, T.N., PEREIRA, A. and KEMMELMEIER, E.G., 2012. Determination and identification of Candida species in dental prosthesis patients. In: Anais da VI Mostra Interna de Trabalhos de Iniciação Científica, 2012, Paraná, Brazil. Maringá: Unicesumar.

LÖFFLER, J., EINSELE, H., HEBART, H., SCHUMACHER, U., HRASTNIK, C. and DAUM, G., 2000. Phospholipid and sterol analysis of plasma membranes of azole-resistant Candida albicans strains. FEMS Microbiology Letters, vol. 185, no. 1, pp. 59-63. PMid:10731607. http://dx.doi.org/10.1016/S03781097(00)00071-9.

LUZ, J.M.Q., MORAIS, T.P.S., BLANK, A.F. and OLIVEIRA, G.S., 2009 [viewed 25 October 2016]. Content, yield and chemical composition of essential oil of basil in poultry litter doses. Horticultura Brasileira [online], vol. 27, pp. 39-353. Available from: https://www.researchgate.net/publication/250046096_ Teor_rendimento_e_composicao_quimica_do_oleo_essencial_ de_manjericao_sob_doses_de_cama_de_frango

MANOHARLAL, R., GORANTALA, J., SHARMA, M., SANGLARD, D. and PRASAD, R., 2010. PAP1 [poly(A) polymerase 1] homozygosity and hyperadenylation are major determinants of increased mRNA stability of CDR1 in azoleresistant clinical isolates of Candida albicans. Microbiology, vol. 156, no. 2, pp. 313-326. PMid:19910410. http://dx.doi. org/10.1099/mic.0.035154-0.

MELO, I.A., LENARDON, L., ALVES, L.R.R.A., GUERRA, R.C. and MENEZES-FILHO, J.F., 2013 [viewed 25 October 2016]. Evaluation of the incidence of Candida spp. associated with the use of partial dentures or complete and profile of patients seen by the dental clinic of a Faculty in Araguaina - TO. Revista Cientifica do ITPAC [online], vol. 6, no. 2, pp. 1-6. Available from: www.itpac.br/arquivos/Revista/62/5.pdf

MENEZES, E.A., CUNHA, M.C.S.O. and CUNHA, F.A., 2011 [viewed 25 October 2016]. Preliminary identification of some species of the genus Candida spp. amid chromogen: results of two years of a multicenter study in Ceara. Revista de Patologia Tropical [online], vol. 40, pp. 297-303. Available from: https:// www.revistas.ufg.br/iptsp/article/viewFile/16761/10207</jrn>.

MUNEER, M.U., QAMAR, K., NAEEM, S. and HAROON, S., 2011 [viewed 25 October 2016]. Candidal count in patients with complete dental. Pakistan Oral \& Dental Journal [online], vol. 31, no. 1, pp. 207-209. Available from: http://www.podj.com.pk/ Jul_2011/47-Podj.pdf

NAIK, A.V. and PAI, R.C., 2011. A study of factors contributing to denture stomatitisin a North Indian community. International Journal of Dentistry, vol. 2011, pp. 1-4. PMid:22194746. http:// dx.doi.org/10.1155/2011/589064.

NEWMAN, D.J. and CRAGG, G.M., 2012. Natural products as sources of new drugs over the 30 Years from 1981 to 2010. Journal of Natural Products, vol. 75, no. 3, pp. 311-335. PMid:22316239. http://dx.doi.org/10.1021/np200906s. 
PIERCE, C.G., SRINIVASAN, A., UPPULURI, P., RAMASUBRAMANIAN, A.K. and LÓPEZ-RIBOT, J.L., 2013. Antifungal therapy with an emphasis on biofilms. Current Opinion in Pharmacology, vol. 13, no. 5, pp. 726-730. PMid:24011516. http://dx.doi.org/10.1016/j.coph.2013.08.008.

SALERNO, C., PASCALE, M., CONTALDO, M., ESPOSITO, V., BUSCIOLANO, M., MILILLO, L., GUIDA, A., PETRUZZI, M. and SERPICO, R., 2011. Candida: associated denture stomatitis. Oral Medicine and Patology, vol. 16, no. 2, pp. 139143. PMid:20711156. http://dx.doi.org/10.4317/medoral.16.e139.

SANGLARD, D., ISCHER, F., PARKINSON, T., FALCONER, D. and BILLE, J., 2003. Candida albicans mutations in the ergosterol biosynthetic pathway and resistance to several antifungal agents. Antimicrobial Agents and Chemotherapy, vol. 47, no. 8, pp. 2404-2412. PMid:12878497. http://dx.doi.org/10.1128/ AAC.47.8.2404-2412.2003.

SARTORATTO, A., MACHADO, A.L.M., DELARMELINA, C., FIGUEIRA, G.M., DUARTE, M.C.T. and REHDER, V.L.G., 2004. Activity of essential oils from aromatic plants used in Brazil.
Brazilian Journal of Microbiology, vol. 35, no. 4, pp. 275-280. http://dx.doi.org/10.1590/S1517-83822004000300001.

SOOKTO, T., SRITHAVAJ, T., THAWEBOON, S., THAWEBOON, B. and SHRESTHA, B., 2013. In vitro effects of Salvia officinalis L. essential oil on Candida albicans. Asian Pacific Journal of Tropical Biomedicine, vol. 3, no. 5, pp. 376-380. PMid:23646301. http://dx.doi.org/10.1016/S2221-1691(13)60080-5.

STRAMANDINOLI, R.T., SOUZA, P.H.C., WESTPHALEN, F.H., BISINELLI, J.C., IGNÁCIO, S.A. and YURGEL, L.S., 2010 [viewed 25 October 2016]. Prevalence of oral candidiasis in hospitalized patients and evaluation of risk factors. Revista SulBrasileira de Odontologia [online], vol. 7, pp. 66-72. Available from: http://www.redalyc.org/articulo.oa?id=153012949009

ZORE, G.B., THAKRE, A.D., JADHAV, S. and KARUPPAYIL, S.M., 2011. Terpenoids inhibit Candida albicans growth by affecting membrane integrity and arrest of cell cycle. Phytomedicine, vol. 18, no. 13, pp. 1181-1190. PMid:21596542. http://dx.doi. org/10.1016/j.phymed.2011.03.008. 